\title{
Gap junction modulation by extracellular signaling molecules: the thymus model
}

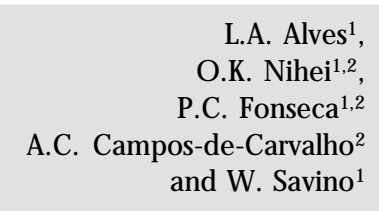

\author{
1Departamento de Imunologia, Instituto O swaldo Cruz, \\ Fundação O swaldo Cruz, Rio de Janeiro, RJ, Brasil \\ IInstituto de Biofísica, Universidade Federal do Rio de Janeiro, \\ Rio de Janeiro, RJ, Brasil
}

\section{Correspondence \\ L.A. Alves \\ Laboratório de Pesquisas sobre o \\ Timo \\ Departamento de Imunologia \\ Instituto O swaldo Cruz, FIOCRUZ \\ Av. Brasil, 4365 \\ 21045-900 Rio de Janeiro, RJ \\ Brasil \\ Fax: + 55-21-280-1589 \\ E-mail: \\ alveslaa@gene.dbbm.fiocruz.br \\ Presented at the Meeting \\ "Gap Junctions in the Nervous and \\ Cardiovascular Systems: Clinical \\ Implications", Rio de Janeiro, RJ, \\ Brazil, June 6-11, 1998.}

Research supported by FAPERJ, CNPq FINEP/BID, FUJB, PADCT/CNPq and PRONEX/CNPq to L.A. Alves, A.C.

Campos-de-Carvalho and W. Savino.

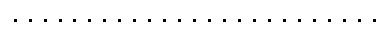

Received July 30, 1999

Accepted November 23, 1999

\section{Abstract}

Gap junctions are intercellular channels which connect adjacent cells and allow direct exchange of molecules of low molecular weight between them. Such a communication has been described as fundamental in many systems due to its importance in coordination, proliferation and differentiation. Recently, it has been shown that gap junctional intercellular communication (GJIC) can be modulated by several extracellular soluble factors such as classical hormones, neurotransmitters, interleukins, growth factors and some paracrine substances. Herein, we discuss some aspects of the general modulation of GJIC by extracellular messenger molecules and more particularly the regulation of such communication in the thymus gland. Additionally, we discuss recent data concerning the study of different neuropeptides and hormones in the modulation of GJIC in thymic epithelial cells. We also suggest that the thymus may be viewed as a model to study the modulation of gap junction communication by different extracellular messengers involved in non-classical circuits, since this organ is under bidirectional neuroimmunoendocrine control.

\section{Introduction}

The establishment of cellular communication was a milestone for the origin and evolution of multicellular organisms. Such a communication can be mediated by 1 ) soluble factors, i.e., hormones, cytokines, growth factors and neurotransmitters, 2) membrane surface molecules, i.e., members of immunoglobulin gene superfamily, integrins, cadherins and other classes of recognition molecules, and 3) ion channels.

Ion channels have been recognized as a fundamental component involved in the mechanisms that most animals use to per- ceive the external world and the internal milieu (mechanoception, nociception, vision, taste, motion and hearing). Gap junction is a particular kind of ion channel that mediates direct transfer of molecules between adjacent cells by a diffusion process.

In vertebrates, the gap junction is an intercellular channel consisting of a dodecameric structure formed by hemichannels (or connexons) of six monomers in each adjacent cell (1). These monomers are proteins named connexins $(\mathrm{Cx})$ that belong to a multigenic family, with at least 14 members already cloned in mammals (1). The most commonly used nomenclature defines a con- 
nexin according to its predicted molecular weight deduced from cDNA sequences and species of origin (1).

These channels permit direct cell-cell exchange of small molecules such as ions, sugars and second messengers between adjacent cells $(1,2)$. It was thought that these channels are permeable to molecules of up to $1 \mathrm{kDa}$ in mammals. However, several studies have demonstrated that many connexins present selectivity for both charge and size. For instance, connexin 43 allows the passage of lucifer yellow while $\mathrm{Cx} 45$ does not (3). In addition, the functionality of heterologous gap junctions has been shown to depend on selective compatibility among different connexins $(3,4)$. In agreement with this, $\mathrm{Cx} 43$ can form functional gap junctions with $\mathrm{Cx} 37,43,45$ and 46 , but not with 26 , $31,32,33,40$ or $50(5)$.

Gap junction channels can be gated, i.e., "opened" or "closed", by several agents including $\mathrm{Ca}^{2+}, \mathrm{H}^{+}$, lipophilic substances, voltage gradients, and hormones (1), the latter generally acting via activation of protein kinases that phosphorylate the cytoplasmic regions of several connexins $(6,7)$, or in some cases by phosphatases $(6,7)$. The presence of connexins has been demonstrated in distinct lympho-hematopoietic organs where their function is not clear (reviewed in Ref. $8)$. In these organs cell-to-cell communication is a key event to tune performance.

In this review, we will focus on the modulation of gap junctions by extracellular messengers in a primary lymphoid organ, the thymus gland. In this organ, bone marrowderived lymphoid precursors undergo a process of differentiation and maturation, culminating with the migration of mature $T$ cells to the periphery. In this process more than $90 \%$ of thymocytes die intrathymically, whereas some are rescued from programmed cell death and are positively selected to ultimately generate the vast majority of the $T$ cell repertoire (9).

Such a differentiation and maturation pro- cess is quite complex, involving a dynamic molecular cross-talk between T cells and the thymic microenvironment, a tridimensional network composed of distinct cell types including epithelial cells, macrophages and dendritic cells, as well as extracellular matrix (ECM) elements (10).

The thymic epithelium is the major component of the thymic microenvironment and determines thymocyte maturation through cell-cell contacts and secretion of a variety of polypeptides including thymic hormones and cytokines (11). Thymic epithelial cells (TEC) can bind to and interact with thymocytes by means of ECM ligands and respective receptors as well as by classical adhesion molecules (12) and, most importantly, by major histocompatibility complex gene products, which present endogenous peptides to the $\mathrm{T}$ cell receptors expressed on the cell membrane of differentiating thymocytes. Recently, we demonstrated the existence of a novel form of cell-to-cell communication in TEC which is mediated by gap junction channels (13).

It is also noteworthy that the thymus is an important component of neuroimmunoendocrine circuits, synthesizing several classical hormones (for example, growth hormone, prolactin and glucocorticoids) which act pleiotropically upon the thymic epithelium (11). Furthermore, the intrathymic production of various neuropeptides, including the neurohypophyseal hormones, oxytocin and vasopressin (11), and vasoactive intestinal peptide (VIP) has been demonstrated (11). In this intriguing network, the data concerning influence of extracellular messenger molecules on gap junction mediated communication begin to be analyzed.

\section{General aspects of gap junction modulation by extracellular signaling molecules}

In vertebrates, gap junctions have been reported in virtually all cell types, with the 
possibility of multiple connexin isoform expression (1). All members of the connexin family have the same putative structure: cytosolic amino and carboxyl termini, four transmembrane domains, and extracellular (two) and cytoplasmic (one) loops. In the primary sequence of these proteins there are several consensus sites for phosphorylation and dephosphorylation, which represent one of the most frequent mechanisms for hormonal modulation of gap junctions and other ion channels.

The first evidence of gap junction modulation by hormones can be credited to Hax et al. (14), who demonstrated the regulation of electrical coupling by cAMP in insect cell cultures, a finding that was confirmed by Loewenstein and co-workers (15). As expected, several extracellular signaling molecules that raised cAMP levels could modulate gap junction communication in different cell types.

Since then, regulation of these channels by hormones and other extracellular signaling molecules such as neurotransmitters, growth factors and cytokines has been demonstrated at the level of transcription, mRNA stability, translation, cytoplasmic traffic and gating $(1,6,7)$. So far, the best studied mechanism operating during these regulatory processes is the phosphorylation/dephosphorylation (6) of connexins, transcription factors and other regulatory proteins. Except for Cx26, all connexins cloned so far can be regulated by phosphorylation/dephosphorylation. Table 1 illustrates some hormones and other extracellular messengers that modulate gap junctions in several cell types. Most of these effects are mediated by protein kinases $\mathrm{A}$ and $\mathrm{C}$, mitogen-activated protein kinase and tyrosine kinase. These kinases can increase or decrease junctional communication depending on the cell type studied. It is not clear why this occurs but perhaps different mixes of connexin isoforms and/or selective activation of other intracellular messenger systems that act on gap junctions might explain the diversity of biological responses. Most of the effects studied thus far are on $\mathrm{Cx} 43$ but several other connexins can be modulated by such substances.

In endocrine glands, a rise in gap junction communication increases the cell response to a given stimulus, increasing hormonal secretion. In Beta cells in Langerhan's islets, the overexpression of $\mathrm{Cx} 43$ leads to an augmented secretion of insulin (16), whereas in adrenal cells an inhibitor of gap junction communication diminishes cortisol secretion (17).

Conversely, in exocrine glands, a rise of gap junction communication in general leads to a decrease in secretion as seen in salivary glands and in the exocrine pancreas (18).

\section{Regulation of thymic gap junctions by extracellular messengers}

We demonstrated that mouse and human TEC are coupled by gap junctions (13), a concept that had been previously postulated by Kendall in the 1980's (19). We also provided evidence for the possible existence of heterologous gap junctions between TEC and thymocytes as well as for the modulation of TEC hormonal secretion by gap junctions.

As shown in Table 1, the majority of the soluble messengers and the respective target cell/organs involved in gap junction modulation studies are those associated with classical endocrine, immunological and nervous circuits such as TSH:thyroid, epinephrine: heart, $\mathrm{T}_{3}, \mathrm{~T}_{4}$ :liver, oxytocin:uterus, FSH:testis, neurotransmitters:neuronal electric coupling, IL-1:liver, and so on. Looking for a more integrative view, the thymus gland could be an interesting model to study gap junction modulation by nonclassical circuits since it is under bidirectional neuroimmunoendocrine control.

Consistent with this idea, it has been demonstrated in rat primary TEC cultures that progesterone, estrogen, testosterone, 
Table 1 - Gap junction modulation by neuroimmunoendocrine soluble products.

ACh, Acetylcholine; BR, bone remodeling; CA, contractile activity; Cx, connexin; DI, differentiation; DTA, dye transfer assay; EF, electrophysiology; EM, electron microscopy; FFEM, freeze-fracture electron microscopy; FRAP, fluorescence recovery after photobleaching method; FSH, follicle-stimulating hormone; GnRHa, gonadotropin-releasing hormone analogue; hCG, human chorionic gonadotropin; HMC, human myoendothelial co-culture; HUVEC, human umbilical vein endothelial cells; ICC, immunocytochemistry; IHC, immunohistochemistry; IF, immunofluorescence; LH, luteinizing hormone; LH-RH, luteinizing hormone-releasing hormone; MAPK, mitogen-activated protein kinase; NB, Northern blotting; ND: not determined; PKA, protein kinase-A; PKC, protein kinase-C; PR, proliferation; PTH, parathyroid hormone; $\mathrm{T}_{3}$, 3,3', 5-triiodo-L-thyronine; SLT, scrape-loading technique; $T_{4}$, L-thyronine; TGF- $\aleph_{1}$, tumor growth factor $\aleph_{1}$; TNF $\alpha$, necrosis factor $\alpha$; TSH, thyrotropin stimulating hormone; WB, Western blotting. *All these parameters depended on the cell type analyzed; **based on cell lines; ***the modulation of the junctional conductance (Gj) was also described (in some cases it involved exclusively $\mathrm{Gj}$ ); $* * * *$ based on goldfish Mauthner cells (M cells); \#modulation of dye coupling and protein expression was represented by the following arrows: $\pi$ (positive modulation), $\downarrow$ (negative modulation) and $k_{n}$ (both effects were described, depending on experimental conditions, cell type or concentration tested, or even the connexin isoform analyzed).

\begin{tabular}{|c|c|c|c|c|c|c|c|c|}
\hline Modulators & $\begin{array}{l}\text { Analyzed cell/ } \\
\text { organ }\end{array}$ & Techniques* & $\begin{array}{l}\text { Connexin } \\
\text { isoform* }\end{array}$ & $\begin{array}{c}\text { Dye } \\
\text { coupling\# }\end{array}$ & $\begin{array}{l}\text { Protein } \\
\text { level\# }\end{array}$ & Protein/kinase* & $\begin{array}{l}\text { Associated } \\
\text { function* }\end{array}$ & References \\
\hline \multicolumn{9}{|l|}{ Cytokines } \\
\hline Interleukin 1 & $\begin{array}{l}\text { Bone, HMC, } \\
\text { HUVEC, liver** }\end{array}$ & $\begin{array}{l}\text { DTA, FRAP, } \\
\text { WB }\end{array}$ & $\mathrm{C} \times 32, \mathrm{Cx} 43$ & $\vee$ & $\vee$ & ND & DI & $36,43,55,56$ \\
\hline Interleukin 2 & Liver & $\mathrm{IHC}$ & ND & ND & $\vee$ & ND & ND & 33 \\
\hline Interleukin 6 & Liver** & DTA, WB & $\mathrm{C} \times 32$ & $\vee$ & $\vee$ & ND & ND & 36 \\
\hline TGF- $ß_{1}$ & $\begin{array}{l}\text { Bone**, } \\
\text { Schwann cells }\end{array}$ & EF, ICC, SLT & $\mathrm{C} \times 43$ & $\vee ク * * *$ & $\pi$ & ND & ND & 29,54 \\
\hline TNF $\alpha$ & HMC, Liver** & DTA, WB & Cx32 & $\vee$ & $\vee$ & ND & DI & 36,56 \\
\hline \multicolumn{9}{|l|}{ Hormones } \\
\hline Estradiol & Bone, uterus & $\begin{array}{l}\text { DTA, FFEM, } \\
\text { IF, IHC, WB }\end{array}$ & $\begin{array}{c}\text { Cx26, Cx32 } \\
\text { Cx43 }\end{array}$ & $v \pi$ & $\pi$ & PKC & CA, BR, PR, DI & $\begin{array}{l}24,28,40,44, \\
45\end{array}$ \\
\hline FSH & Testis & DTA, FRAP & ND & $\pi$ & ND & ND & ND & 69 \\
\hline $\mathrm{GnRHa}$ & Ovary & WB & $\mathrm{C} \times 43$ & ND & $\vee$ & PKC & ND & 46 \\
\hline Glucagon & Liver & ICC, SLT & Cx26, Cx32 & ND & $\pi$ & ND & ND & 51 \\
\hline Glucocorticoid & Liver** & DTA, SLT, WB & $C \times 26, C \times 32$ & $\pi$ & $\pi$ & ND & ND & 51 \\
\hline hCG & Ovary, uterus & FRAP, IF, WB & $\mathrm{C} \times 43$ & $\pi$ & $\vee \pi$ & PKA & CA, DI & $24,25,31$ \\
\hline $\mathrm{LH}$ & Ovary, uterus & FRAP, WB & $\mathrm{C} \times 43$ & $\pi$ & $\hat{v}$ & $\begin{array}{c}\text { PKC and probably } \\
\text { PKA }\end{array}$ & CA & 24,46 \\
\hline Insulin & Xenopus oocytes & $\mathrm{EF}$ & $\mathrm{C} \times 43$ & $\nvdash * * *$ & ND & Probably MAPK & ND & 35 \\
\hline Melatonin & Liver & IHC, SLT, WB & Cx32 & $\pi$ & $\pi$ & ND & Antiproliferative & 26 \\
\hline Oxytocin & Ovary, uterus & IF, WB & $\mathrm{C} \times 43$ & ND & $\pi$ & ND & ND & 24,31 \\
\hline Progesterone & Uterus & $\begin{array}{c}\text { FFEM, IF,IHC, } \\
\text { WB }\end{array}$ & $\begin{array}{c}\text { Cx26, Cx32 } \\
\text { Cx43 }\end{array}$ & ND & $\vee \pi$ & ND & CA, PR, DI & $24,28,39,45$ \\
\hline Prolactin & Pancreas & DTA & ND & $\pi$ & ND & ND & ND & 50 \\
\hline PTH & Bone & DTA, WB & Cx43 & $\pi$ & $\pi$ & ND & ND & 27,70 \\
\hline$T_{3}$ & Liver** & DTA, WB & $\mathrm{C} \times 43$ & $\pi$ & $\pi$ & ND & ND & 52 \\
\hline $\mathrm{T}_{4}$ & Liver** & DTA, WB & $\mathrm{C} \times 43$ & $\pi$ & $\pi$ & ND & ND & 52 \\
\hline Testosterone & $\begin{array}{l}\text { Epididymis, } \\
\text { pituitary gland }\end{array}$ & $\begin{array}{l}\text { EM, IHC, } \\
\text { WB }\end{array}$ & Cx43 & $\forall \pi$ & $\vee$ & ND & ND & 23,38 \\
\hline TSH & Thyroid & DTA & $\mathrm{C} \times 32, \mathrm{C} \times 43$ & $\pi$ & $\pi$ & Probably PKA & DI & 22,41 \\
\hline \multicolumn{9}{|c|}{ Neurotransmitters } \\
\hline $\mathrm{ACh}$ & Eye, hippocampus & DTA, EF & ND & $\nvdash * * *$ & ND & ND & ND & $30,42,72$ \\
\hline Dopamine & $\begin{array}{l}\text { Hippocampus, } \\
\text { retina }\end{array}$ & DTA, EF & ND & $\vee * * *$ & ND & ND & ND & $34,42,53$ \\
\hline Epinephrine & Heart & $\mathrm{EF}$ & ND & $\prod * * *$ & ND & ND & ND & 71 \\
\hline Glutamate & $\begin{array}{l}\text { Cerebellum, } \\
\text { M cell**** }\end{array}$ & DTA, EF & ND & $\forall * * *$ & ND & ND & ND & 37,47 \\
\hline Norepinephrine & $\begin{array}{l}\text { Cortex, pineal } \\
\text { gland }\end{array}$ & DTA, EF, WB & $\mathrm{C} \times 26$ & $\vee ク * * *$ & ND & PKA & ND & $32,48,49,71$ \\
\hline Serotonin & Cortex & DTA, EF & ND & $\vee$ & ND & PKC & ND & 32 \\
\hline
\end{tabular}


corticotropin, growth hormone, interleukin$1 \alpha$, interleukin-1ß, $\gamma$-aminobutyric acid (GABA), neuropeptide $Y$, vasoactive intestinal peptide, substance $\mathrm{P}$, and histamine reduce dye coupling whereas acetylcholine and the $\beta$-adrenergic agonist isoproterenol have no effect (20,21; see Table 2).

Yet, in contrast to some of these data, we found that VIP and vasopressin increase dye coupling in one mouse TEC line and primary cultures of thymic nurse cells. Supporting this idea, 8Br-cAMP, a permeable analog of cAMP (secondary messenger of VIP and vasopressin), can also increase the degree of inter-TEC dye coupling (Alves LA, Figueira $\mathrm{G}$, Savino $\mathrm{W}$ and Campos-de-Carvalho AC, unpublished results). Additionally, we found an increase in dye coupling in a rat cell line (clone IT45-R1, provided by Dr. Tsumeroshi Itoh, Tohoku University, Sendai, Japan) when cells were treated with dexamethasone (Figure 1). Much work is still necessary in order to obtain a clear view of the possible role of gap junctions in thymus tissue. Furthermore, it is essential to understand the multiple levels of regulation of intercellular communication by way of gap junctions in the thymus gland. Presently, the mechanisms by which dye coupling increases or decreases in thymic epithelial cells when these cells are treated with extracellular messenger molecules are not known. Table 2 summarizes the effects of several extracellular molecules on inter-TEC dye coupling, as well as the expression of the respective receptors. One can see that receptors for some putative modulators have not yet been formally characterized in TEC, and that several hormones for which receptors are expressed have not been studied for their potential effects on

Table 2 - Neuroendocrine modulators of inter-TEC gap junctions.

ACh, Acetylcholine; ACTH, adrenocorticotropin hormone; AR, auto-radiography; CGRP, calcitonin gene-related peptide; $\mathrm{EF}$, electrophysiology; GABA, $\gamma$-aminobutyric acid; $\mathrm{GH}$, growth hormone; 5-HT, 5hydroxytryptamine; IHC, immunohistochemistry; IL1- $\alpha$, interleukin-1 $\alpha$; IL1-ß , interleukin-1ß; LM, light microscopy; NB, Northem blotting; NE, no effect; NPY, neuropeptide Y; PA, pharmacological analysis; RT-PCR, reverse transcription-polymerase chain reaction; RTM, reticuloepithelial cells of thymus medulla; SPA, Scatchard plot analysis; SP, substance P; TEC, thymic epithelial cells; VIP, vasoactive intestinal peptide; WB, Western blotting. *Summarized from Refs. 20 and 21; **the receptor expression is represented by the following signals: + (positive expression), - (not found) or ND (not determined); ***related to receptor characterization studies; "\#odulation of dye coupling is represented by the arrows: $\downarrow$ (negative modulation).

\begin{tabular}{|c|c|c|c|c|c|}
\hline Modulators* & Dye coupling*\# & Cell type*** & Receptor** & Approach & References*** \\
\hline $\mathrm{ACh}$ & NE & Thymic extract & + & NB, RT-PCR & 59 \\
\hline ACTH & 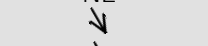 & & ND & & \\
\hline CGRP & $\checkmark$ & TEC & + & RT-PCR, IHC & 62 \\
\hline GABA & $v$ & & - & $\mathrm{EF}$ & 68 \\
\hline $\mathrm{GH}$ (rat) & $v$ & Type-1 TEC & + & NB, WB, RT-PCR, IHC & 61 \\
\hline Histamine & $\vee$ & & ND & & \\
\hline $5-\mathrm{HT}$ & NE & & ND & & \\
\hline ILI- $\alpha$ & $\Downarrow$ & & ND & & \\
\hline ILI-ß & $\forall$ & & ND & & \\
\hline Isoproterenol & NE & Thymic extract, TEC & + & PA, NB, RT-PCR & 66,67 \\
\hline NPY & $\vee$ & & - & LM, IHC & 63 \\
\hline Oestrogen & $\vee$ & RTM & + & $\mathrm{IHC}$ & 58 \\
\hline Progesterone & $\vee$ & RTM & + & SPA, IHC & 57,58 \\
\hline SP & $\vee$ & & - & $A R$ & 60 \\
\hline Testosterone & $\vee$ & Thymic extract & + & SPA & 64,65 \\
\hline Thymulin & NE & & ND & & \\
\hline VIP & $\vee$ & Cortical/medullar TEC & + & RT-PCR, IHC, AR & 60,62 \\
\hline
\end{tabular}


Figure 1 - Increase in gap junctional communication induced by dexamethasone in a rat epithelial cell line. TEC were treated with $10^{-6} \mathrm{M}$ dexamethasone for $48 \mathrm{~h}$, and intercellular communication was evaluated by dye transfer assay using the fluorochrome lucifer yellow (LY). A, Microscopy fields (phase contrast and fluorescence, respectively, in the left and right panels) depicting the injected cell $(*)$ and those that were coupled when LY was injected (magnification 320X). B, Histograms showing the pattern of coupling degree of control and dexamethasone-treated cells. The analysis comprises 100 microinjections per group.
TEC gap junctions. For instance, in human TEC the GABA receptor was not found. Yet, when this neurotransmitter is applied to rat
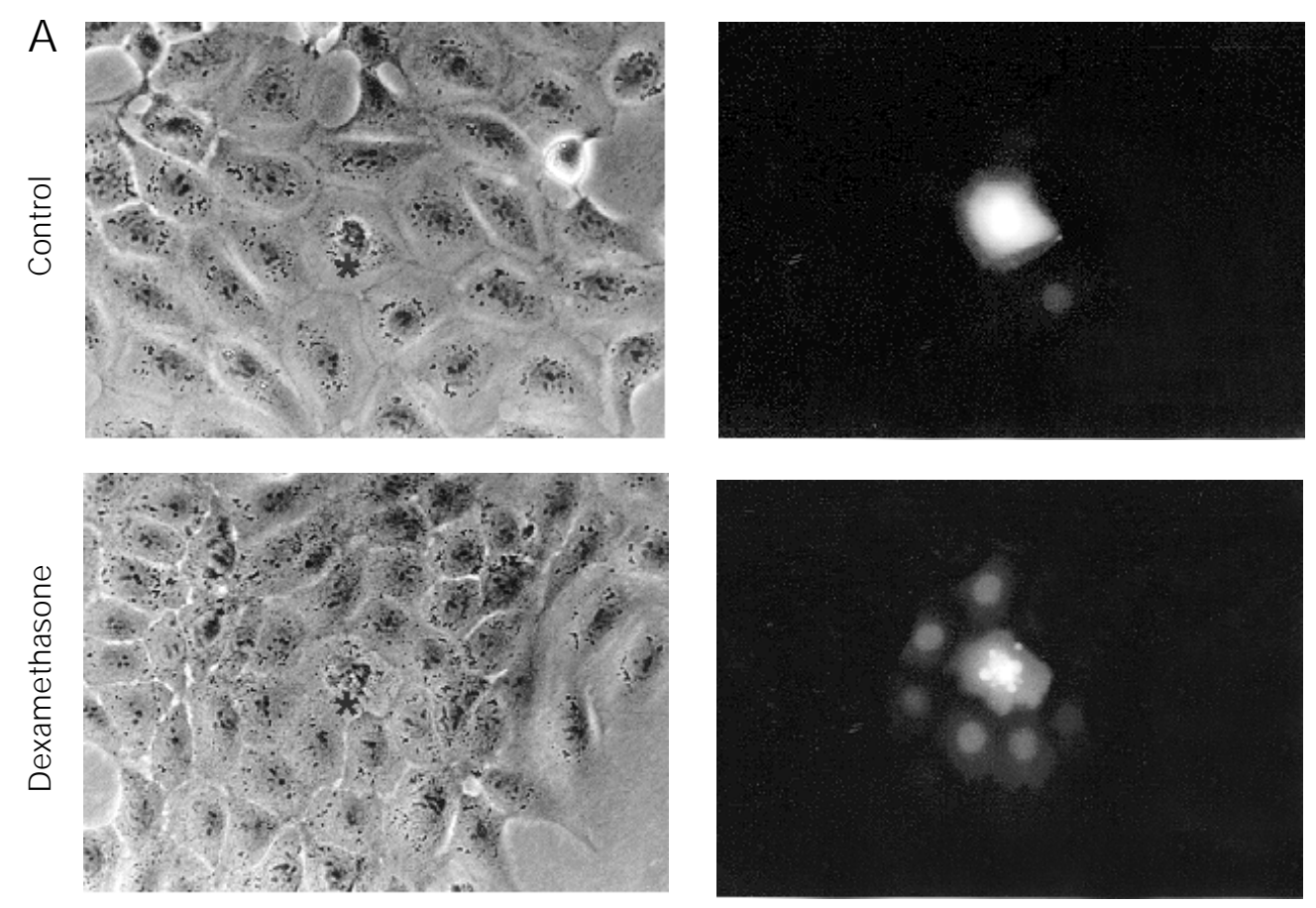

B

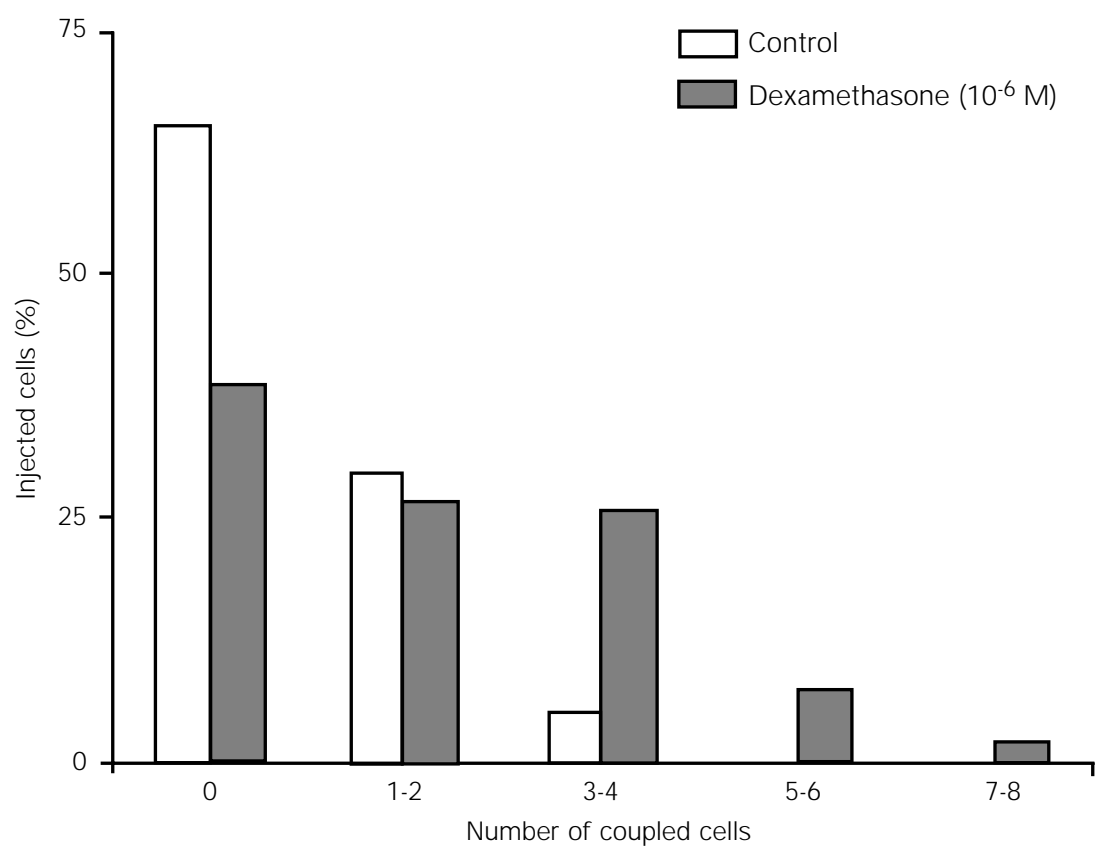




\section{Conclusion and perspectives}

Taken together, the data discussed herein indicate that inter-TEC gap junctions in the thymus gland can be modulated by several extracellular messenger molecules, which may influence the putative functions of gap junctions in the thymic epithelium. It remains to be defined at what level this modu- lation occurs and to what extent it influences thymus physiology.

\section{Acknowledgments}

We would like to thank Dr. Fernando Pires de Farias for a critical review of the manuscript.

\section{References}

1. Bruzzone R, White TW \& Paul DL (1996). Connections with connexins: the molecular basis of direct intercellular signaling. European J ournal of Biochemistry, 238: 1-27.

2. Sáez J C, Connor J A, Spray DC \& Bennett MVL (1989). Hepatocyte gap junctions are permeable to the second messengers inositol 1,4,5-triphosphate and calcium ions. Proceedings of the National Academy of Sciences, USA, 86: 2708-2712.

3. Steinberg TH, Civitelli R, Geist ST, Robertson AJ , Hick E, Veenstra RD, Wang $\mathrm{HZ}$, Warlow PM, Westphale EM, Laing J G \& Beyer EC (1994). Connexin43 and connexin45 form gap junctions with different molecular permeabilities in osteoblastic cells. EMBO J oumal, 15: 744-750.

4. White TW, Paul DL, Goodenough DA \& Bruzzone R (1995). Functional analysis of selective interactions among rodent connexins. Molecular Biology of the Cell, 6 : 459-470.

5. Elfgang $\mathrm{C}$, Eckert $\mathrm{R}$, Lichtenberg-Frate $\mathrm{H}$, Butterweck A, Traub O, Klein RA, Hulser DF \& Willecke K (1995). Specific permeability and selective formation of gap junction channels in connexin-transfected HeLa cells. J ournal of Cell Biology, 129: 805-817.

6. Sáez J C, Martinez $A D$, Branes $M C$ \& Gonzalez HE (1998). Regulation of gap junctions by protein phosphorylation. Brazilian J ournal of Medical and Biological Research, 31: 593-600.

7. Stagg RB \& Fletcher WH (1990). The hormone-induced regulation of contact-dependent cell-cell communication by phosphorylation. Endocrine Reviews, 192: 302325.

8. Alves LA, Campos-de-Carvalho AC \& Savino W (1998). Gap junctions: a novel route for cell-cell communication in the immune system? Immunology Today, 19: 269-275.
9. Fowlkes BJ \& Pardoll DM (1989). Molecular and cellular events of T cell development. Advances in Immunology, 44: 207264.

10. Anderson G, Moore NC, Owen JJT \& J enkinson EJ (1996). Cellular interactions in thymocyte development. Annual Reviews in Immunology, 14: 73-99.

11. Dardenne M \& Savino W (1994). Control of thymus physiology by peptide hormones and neuropeptides. Immunology Today, 15: 518-523.

12. Savino W, Villa-Verde DMS \& LannesVieira J (1993). Extracellular matrix proteins in intrathymic $\mathrm{T}$ cell migration and differentiation? Immunology Today, 14: 158-161.

13. Alves LA, Campos-de-Carvalho AC, CimeLima EO, Rocha-e-Souza CM, Dardenne M, Spray DC \& Savino W (1995). Functional gap junctions in thymic epithelial cells are formed by connexin 43 . European J oumal of Immunology, 25: 431-437.

14. Hax WMA, van-Venrooij GEPM \& Vossenberg J BJ (1974). Cell communication: a cyclic-AMP mediated phenomenon. J oumal of Membrane Biology, 19: 253-266.

15. Flagg-Newton J L, Dahl G \& Loewenstein WR (1981). Cell junction and cyclic AMP: 1. Up regulation of junctional membrane permeability and junctional membrane particles by administration of cyclic nucleotide or phosphodiesterase inhibitor. J ournal of Membrane Biology, 63: 105121.

16. Vozzi C, Bosco D, Dupont E, Charollais A \& Meda P (1997). Hyperinsulinemia-induced hypoglycemia is enhanced by overexpression of connexin 43. Endocrinology, 138: 2879-2885.

17. Munari-Silem $Y$, Lebrethon MC, Morand I, Rousset B \& Saez J M (1995). Gap junction-mediated cell-to-cell communication in bovine and human adrenal cells. A pro- cess whereby cells increase their responsiveness to physiological corticotropin concentrations. J oumal of Clinical Investigation, 95: 1429-1439.

18. Meda P, Pepper MS, Traub O, Willecke K, Gros D, Beyer E, Nicholson B, Paul D \& Orci L (1993). Differential expression of gap junction connexins in endocrine and exocrine glands. Endocrinology, 133: 2371-2378.

19. Kendall MD (1986). The syncytial nature of epithelial cells in the thymic cortex. J oumal of Anatomy, 147: 95-106.

20. Head GM, Mentlein R, von-Patay B, Downing J EG \& Kendall MD (1998). Neuropeptides exert direct effects on rat thymic epithelial cells in culture. Developmental Immunology, 6: 95-104.

21. Head GM, Mentlein R, Kranz A, Downing J EG \& Kendall MD (1997). Modulation of dye-coupling and proliferation in cultured rat thymic epithelium by factors involved in thymulin secretion. J ournal of Anatomy, 191: 355-365.

22. Munari-Silem $Y$, Audebet $C \&$ Rousset $B$ (1991). Hormonal control of the cell communication: Regulation by thyrotropin of the gap junction-mediated dye transfer between thyroid cells. Endocrinology, 128: 3299-3308.

23. Cyr DG, Hermo L \& Laird DW (1996). Immunocytochemical localization and regulation of connexin 43 in the adult rat epididymis. Endocrinology, 137: 14741484

24. Ambrus $G \&$ Rao CV (1994). Novel regulation of pregnant human myometrial smooth muscle cell gap junctions by human chorionic gonadotropin. Endocrinology, 135: 2772-2779.

25. Cronier L, Bastide B, Herve J C, Deleze J \& Malassine A (1994). Gap junctional communication during human trophoblast differentiation: Influence of human chorionic gonadotropin. Endocrinology, 135: 402-408. 
26. Kojima T, Mochizuki C, Mitaka $T \&$ Mochizuki Y (1997). Effects of melatonin on proliferation, oxidative stress and $\mathrm{C} \times 32$ gap junction protein expression in primary cultures of adult rat hepatocytes. Cell Structure and Function, 22: 347-356.

27. Civitelli $R$, Ziambaras $K$, Warlow PM, Lecanda F, Nelson T, Harley J, Atal N, Beyer EC \& Steinberg TH (1998). Regulation of connexin 43 expression and function by prostaglandin $\mathrm{E}_{2}\left(\mathrm{PGE}_{2}\right)$ and parathyroid hormone (PTH) in osteoblastic cells. J ournal of Cellular Biochemistry, 68: 8-21.

28. Lye SJ, Nicholson BJ, Mascarenhas M, Mackenzie L \& Petrocelli T (1993). Increased expression of connexin-43 in the rat myometrium during labor is associated with an increase in the plasma estrogen:progesterone ratio. Endocrinology, 132: 2380-2386.

29. Chiba H, Sawada N, Oyamada M, Kojima T, Iba K, Ishii S \& Mori M (1994). Hormonal regulation of connexin 43 expression and gap junctional communication in human osteoblastic cells. Cell Structure and Function, 19: 173-177.

30. Stelling J W \& J acob TJ (1997). Functional coupling in bovine ciliary epithelial cells is modulated by carbachol. American J ournal of Physiology, 273: C1876-C1881.

31. Klan-Dawood FS, Yang J \& Dawood MY (1998). Hormonal regulation of connexin43 in baboon corpora lutea. J ournal of Endocrinology, 157: 405-414.

32. Rorig B \& Sutor B (1996). Serotonin regulates gap junction coupling in the developing rat somatosensory cortex. European J oumal of Neuroscience, 8: 1685-1695.

33. Wadamori K, Oka M, Tokuda N, Fujikura Y, Hazama S, Fukumoto $T \&$ Suzuki T (1996). Influence of continuous interleukin-2 administration via the portal vein on liver regeneration following partial hepatectomy in rats. Hepatology, 23: 15781583.

34. Mcmahon DG, Knapp AG \& Dowling J E (1989). Horizontal cell gap junctions: single-channel conductance and modulation by dopamine. Proceedings of the National Academy of Sciences, USA, 86: 76397643.

35. Homma N, Alvarado J L, Coombs W, Stergiopoulos K, Taffet SM, Lau AF \& Delmar M (1998). A particle-receptor model for the insulin-induced closure of connexin43 channels. Circulation Research, 83: 27-32.

36. Temme A, Traub O \& Willecke K (1998). Downregulation of connexin32 protein and gap-junctional intercellular communi- cation by cytokine-mediated acute-phase response in immortalized mouse hepatocytes. Cell and Tissue Research, 294: 345350.

37. Pereda AE \& Faber DS (1996). Activitydependent short-term enhancement of intercellular coupling. J ournal of Neuroscience, 16: 983-992.

38. Soji T\& Herbert DC (1990). Intercellular communication within the rat anterior pituitary gland. II. Castration effects and changes after injection of luteinizing hormone-releasing hormone ( $\mathrm{LH}-\mathrm{RH})$ or testosterone. Anatomical Record, 226: 342346.

39. Orsino A, Taylor CV \& Lye SJ (1996). Connexin-26 and connexin-43 are differentially expressed and regulated in the rat myometrium throughout late pregnancy and with the onset of labor. Endocrinology, 137: 1545-1553.

40. Doualla-Bell F, Lye SJ , Labrie F \& Fortier MA (1995). Differential expression and regulation of connexin43 and cell-cell coupling in myocytes from the circular and longitudinal layers of bovine myometrium. Endocrinology, 136: 5322-5328.

41. Munari-Silem $Y$, Guerrier A, Fromaget $C$, Rabilloud R, Gros D \& Rousset B (1994). Differential control of connexin-32 and connexin-43 expression in thyroid epithelial cells: evidence for a direct relationship between connexin-32 expression and histiotypic morphogenesis. Endocrinology, 135: 724-734.

42. Velazquez J LP, Han D \& Carlen PL (1997). Neurotransmitter modulation of gap junctional communication in the rat hippocampus. European J ournal of Neuroscience, 9: 2522-2531.

43. Dorshkind K, Green L, Godwin A \& Fletcher WH (1993). Connexin-43-type gap junctions mediate communication between bone marrow stromal cells. Blood, 82: 38-45.

44. Massas R, Korenstein R \& Benayahu D (1998). Estrogen modulation of osteoblastic cell-to-cell communication. J oumal of Cellular Biochemistry, 69: 282-290.

45. Risek B, Klier G, Phillips A, Hahn DW \& Gilula NB (1995). Gap junction regulation in the uterus and ovaries of immature rats by estrogen and progesterone. J ournal of Cell Science, 108: 1017-1032.

46. Granot I \& Dekel N (1994). Phosphorylation and expression of connexin-43 ovarian gap junction protein are regulated by luteinizing hormone. J ournal of Biological Chemistry, 269: 30502-30509.

47. Muller T, Moller T, Neuhaus J \& Kettenmann H (1996). Electrical coupling among Bergmann glial cells and its modulation by glutamate receptor activation. Glia, 17: 274-284.

48. Saez J C, Berthoud VM, Kadle R, Traub O, Nicholson BJ , Bennett MV \& Dermietzel R (1991). Pinealocytes in rats: connexin identification and increase in coupling caused by norepinephrine. Brain Research, 24: 265-275.

49. Rorig B, Klausa G \& Sutor B (1995). Betaadrenoceptor activation reduces dye-coupling between immature rat neocortical neurones. NeuroReport, 6: 1811-1815.

50. Michaels RL, Sorenson RL, Parsons J A \& Sheridan JD (1987). Prolactin enhances cell-to-cell communication among ß-cells in pancreatic islets. Diabetes, 36: 10981103.

51. Kojima T, Mitaka T, Shibata $Y \&$ Mochizuki $Y$ (1995). Induction and regulation of connexin 26 by glucagon in primary cultures of adult rat hepatocytes. J oumal of Cell Science, 108: 2771-2780.

52. Stock A, Sies $H \& \&$ Stahl W (1998). Enhancement of gap junctional communication and connexin 43 expression by thyroid hormones. Biochemical Pharmacology, 55: 475-479.

53. Hampson ECG, Vaney DI \& Weiler R (1992). Dopaminergic modulation of gap junction permeability between amacrine cells in mammalian retina. J ournal of Neuroscience, 12: 4911-4922.

54. Chandross KJ, Chanson M, Spray DC \& Kessler J A (1995). Transforming growth factor- $ß_{1}$ and forskolin modulate gap junctional communication and cellular phenotype of cultured Schwann cells. J ournal of Neuroscience, 15: 262-273.

55. Hu WW \& Xie H (1994). Interleukin-1 $\alpha$ suppresses gap junction-mediated intercellular communication in human endothelial cells. Experimental Cell Research, 213: 218-223.

56. Hu J \& Cotgreave IA (1997). Differential regulation of gap junctions by proinflammatory mediators in vitro. J oumal of Clinical Investigation, 99: 2312-2316.

57. Fujii-Hanamoto $\mathrm{H}$, Grossman C], Roselle GA, Mendenhall CL \& Seiki K (1990). Nuclear progestin receptors in rat thymic tissue. Thymus, 15: 31-45.

58. Kawashima I, Sakabe K, Seiki K, FujiiHanamoto H, Akatsuka A \& Tsukamoto H (1991). Localization of sex steroid receptor cells, with special reference to thymulin (FTS)-producing cells in female rat thymus. Thymus, 18: 79-93.

59. Mihovilovic $M \&$ Roses AD (1993). Expression of $\alpha-3, \alpha-5$ and $\beta-4$ neuronal acetylcholine receptor subunit transcripts in 
normal and myasthenia gravis thymus. J ournal of Immunology, 151: 6517-6524.

60. Reubi J C, Horisberger U, Kappeler A \& Laissue J A (1998). Localization of receptors for vasoactive intestinal peptide, somatostatin and substance $P$ in distinct compartments of human lymphoid organs. Blood, 92: 191-197.

61. Hull KL, Thiagarajah A \& Harvey S (1996). Cellular localization of growth homone receptors/binding proteins in immune tissues. Cell and Tissue Research, 286: 6980.

62. Marie J C, Wakkach A, Coudray AM, Chastre E, Berrih-Aknin S \& Gespach C (1999). Functional expression of receptors for calcitonin gene-related peptide, calcitonin, and vasoactive intestinal peptide in the human thymus and thymomas from myasthenia gravis patients. J ournal of Immunology, 162: 2103-2112.

63. Weihe $E$, Muller S, Fink $T \&$ Zentel HJ (1989). Tachykinins, calcitonin gene-related peptide and neuropeptide $Y$ in nerves of the mammalian thymus: inter- actions with mast cells in autonomic and sensory neuroimmunomodulation? Neuroscience Letters, 100: 77-82.

64. Grossman CJ, Nathan P, Taylor BB \& Sholiton LJ (1979). Rat thymic dihydrotestosterone receptor: preparation, location and physiochemical properties. Steroids, 34: 539-553.

65. Grossman CJ, Sholiton LJ \& Helmsworth J A (1983). Characteristics of the cytoplasmic and nuclear dihydrotestosterone receptors of human thymic tissue. Steroids, 42: 11-22.

66. Kurz B, Feindt J , von-Gaudecker B, Kranz A, Loppnow H \& Mentlein R (1997). Betaadrenoceptor-mediated effects in rat cultured thymic epithelial cells. British J ournal of Phamacology, 120: 1401-1408.

67. Marchetti B, Morale MC, Paradis P \& Bouvier $M$ (1994). Characterization, expression, and hormonal control of a thymic $B_{2-}$ adrenergic receptor. American J ournal of Physiology, 265: E718-E731.

68. Siara J, Rudel R \& Marx A (1991). Absence of acetylcholine-induced current in epithelial cells from thymus glands and thymomas of myasthenia gravis patients. Neurology, 41: 128-131.

69. Pluciennik F, J offre $M \&$ \& Délèze J (1994). Follicle-stimulating hormone increases gap junction communication in Sertoli cells from immature rat testis in primary culture. J ournal of Membrane Biology, 139: 81-96.

70. Massas R \& Benayahu D (1998). Parathyroid hormone effect on cell-to-cell communication in stromal and osteoblastic cells. J ournal of Cellular Biochemistry, 69: 81-86.

71. De-Mello WC (1997). Influence of $\alpha$-adrenergic-receptor activation on junctional conductance in heart cells: interaction with ß-adrenergic agonists. J ournal of Cardiovascular Pharmacology, 29: 273-277.

72. Chanson M, Mollard P, Meda P, Suter S \& J ongsma HJ (1999). Modulation of pancreatic acinar cell to cell coupling during ACh-evoked changes in cytosolic $\mathrm{Ca}^{2+}$. J ournal of Biological Chemistry, 274: 282287. 